\title{
Assessment of the Relationship Between the Femorotibial Angle and Meniscal Injury with Radiologic Imaging Methods
}

\section{Femorotibial Açı ile Meniskal Yaralanmalar Arasındaki ilişkinin Radyolojik Görüntüleme Yöntemleri Ile Birlikte Değerlendirilmesi}

\author{
๑ Emrah Sayıt, ๑ Aslı Tanrıvermiş Sayıt* \\ University of Health Sciences, Samsun Training and Research Hospital, Clinic of Orthopedics, Samsun, Turkey \\ *Ondokuz Mayıs University Faculty of Medicine, Department of Radiology, Samsun, Turkey
}

\section{Abstract}

\begin{abstract}
Aim: Our aim in this study was to determine the relationship between femorotibial angle and meniscal injuries and to evaluate the relationship between femorotibial angle and development of osteoarthritis.
\end{abstract}

Methods: One hundred and one patients aged $>18$ years who had undergone knee magnetic resonance imaging and anterior-posterior radiographs were retrospectively re-evaluated. All magnetic resonance imaging scans of the knee was evaluated for meniscal injury, and femorotibial angle measurements were performed from the knee anterior-posterior radiographs. The relationship between femorotibial angle values and presence of meniscal injury was analyzed statistically.

Results: In total, 101 knee joints belonging to 101 patients (55 female, 46 male) were included in the study. The median femorotibial angle value was $4^{\circ} \mathrm{C}(1-12)$ in the knee joints with medial meniscal injury and $4^{\circ} \mathrm{C}(0-12)$ in the normal knee joints. This was not statistically significant $(p>0.01)$. The median femorotibial angle value was $5^{\circ} \mathrm{C}(1$ $12)$ in the knee joints with lateral meniscal injury and $4^{\circ} \mathrm{C}(0-12)$ in the normal knee joints. This was not statistically significant $(p>0.01)$.

Conclusion: In our study, there was no statistically significant relationship between femorotibial angle values and presence of injury in medial and lateral menisci.

Keywords: Femorotibial angle, meniscal injury, radiographs, magnetic resonance imaging
Öz

Amaç: Çalışmamızın amacı femorotibial açı ile menisküs yaralanmaları arasındaki ilişkiyi saptamak ve femorotibial açı ile osteoartrit gelişimi arasındaki ilişkiyi değerlendirmektir.

Yöntemler: Kliniğimizde diz manyetik rezonans görüntüleme ve diz ön arka radyografileri bulunan 18 yaşının üzerinde 101 hasta retrospektif olarak değerlendirildi. Menisküs yaralanmaları için diz manyetik rezonans görüntüleri değerlendirildi. Femorotibial açı ölçümleri ise diz ön arka radyografilerden yapıldı. Femorotibial açı değerleri ile menisküs yaralanması arasındaki ilişki istatistiksel olarak analiz edildi.

Bulgular: Çalışmamıza 101 hastaya ait 101 diz eklemi dahil edildi. Yüz bir hastanın 55'i kadın olup 46'sı erkekti. Medial menisküs yaralanması bulunan diz ekleminde median femorotibial açı değeri $4^{\circ} \mathrm{C}(1-12)$ olup normal diz ekleminde $4^{\circ} \mathrm{C}(0-12)$ idi. íki grup arasında istatistiksel olarak anlamlı ilişiki saptanmadı $(p>0,01)$. Lateral menisküs yaralanması olan diz ekleminde median femorotibial açı değeri $5^{\circ} \mathrm{C}(1-12)$ olup normal diz ekleminde $4^{\circ} \mathrm{C}(0-12)$ idi. İki grup arasında istatistiksel olarak anlamlı ilişiki saptanmadı $(p>0,01)$.

Sonuç: Çalışmamızda femorotibial açı değerleri ile medial ve lateral menisküslerde yaralanma arasında istatistiksel olarak anlamlı bir ilişki saptanmadı.

Anahtar Sözcükler: Femorotibial açı, menisküs yaralanması, radyografi, manyetik rezonans görüntüleme
Address for Correspondence/Yazışma Adresi: Aslı Tanrıvermiş Sayıt Ondokuz Mayıs University Faculty of Medicine, Department of Radiology, Samsun, Turkey Phone: +90 5324949082 E-mail: draslitanrivermissayitsayit@gmail.com ORCID ID: orcid.org/0000-0003-2861-156X Received/Geliş Tarihi: 26 April 2018 Accepted/Kabul Tarihi: 18 June 2018
${ }^{\circ}$ Copyright 2019 by The Medical Bulletin of University of Health Sciences Haseki Training and Research Hospital

The Medical Bulletin of Haseki published by Galenos Yayınevi.

'Telif Hakkı 2019 Sağlık Bilimleri Üniversitesi Haseki Eğitim ve Araştırma Hastanesi Haseki Tıp Bülteni, Galenos Yayınevi tarafından yayınlanmıştır. 


\section{Introduction}

The meniscus provides an important role in maintaining joint congruity and stability. The primary biomechanical function of the meniscus is distributing the axial load. Other functions are absorbing shock, and providing lubrication and nutrition to the knee joint (1). Load distribution problems in the knee joint can be seen in meniscal injuries (2). Degenerative arthritis may occur when the stress increases on the articular cartilage (1). The load is unproportionally transmitted to the medial compartment of the knee during walking (3). Malalignment is an important biomechanical factor in the progression of knee osteoarthritis (OA) (4). The intersection of the femoral and the tibial axes forms the femorotibial angle (FTA) which is normally $5^{\circ} \mathrm{C}-7^{\circ} \mathrm{C}(5)$. Loading on the medial and lateral menisci and compartments changes when the angle changes (6).

Our aim in this study was to determine the relationship between FTA and meniscal injuries and to evaluate the relationship between FTA and the development of OA.

\section{Methods}

\section{Patients}

Review board approval was obtained to review the records of patients who had undergone anterior-posterior (AP) radiography of the knee joint and knee magnetic resonance imaging (MRI) between November 2017 and January 2018. One hundred and one patients (46 male, 55 female) aged $>18$ years who had undergone knee MRI and AP radiography at our department were retrospectively reevaluated from the picture archiving and communication system. Patients who had acute trauma, ligamentous knee joint injury, previous knee surgery, and benign or malignant mass lesion were not included in the study.

Written informed consent was obtained from the patients who participated in this study.

Institutional Review Board approval (meeting number: 2018/1, date: 09.01.2018, protocol number: 7) was obtained from Samsun Education and Research Hospital.

\section{Radiologic Protocol and Imaging}

The MRI images were obtained with a 1.5 Tesla MAGNETOM Aera ${ }^{\circledR}$ MRI device (Siemens Healthcare, Erlangen, Germany) with a knee coil. Scan sequences included a sagittal T1-weighted turbo spin-echo (TR/TE: 500/17), a sagittal proton density spectral attenuated inversion recovery (PD SPAIR) (TR/TE: 3000/30), an axial PD SPAIR (TR/TE: 3353/30), a coronal T2-weighted SPAIR (TR/TE: 2500/50), sagittal T2-weighted SPAIR (TR/ TE: 2619/62), and an axial T2-weighted SPAIR (TR/TE: 3353/30)-slice thickness, $3.5 \mathrm{~mm}$ and gap, $0.3 \mathrm{~mm}$.

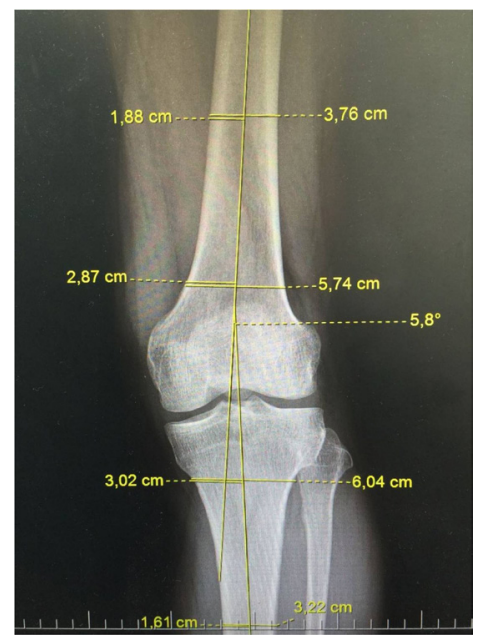

Figure 1. Measurement of the femorotibial angle using AP knee radiography

AP: Anotomy and physiology

All knee MRIs were evaluated for meniscal injury, and FTA measurements were performed from the knee AP radiographs. Evaluation of OA was performed on the knee MRI and the knee radiographs. In addition, the anterior cruciate ligaments ( $A C L$ ) were evaluated on the knee MRIs.

The anatomic FTA was calculated using the anatomical axes of the femur and the tibia on the AP knee radiographs. The FTAs were measured by drawing a line along the axis of the femoral shaft to intersect the corresponding line drawn through the tibial shaft (Figure 1). The FTAs were noted in these patients. In addition, a meniscal evaluation was performed through an MRI for each patient. Meniscal injuries were evaluated in at least two consecutive images. The assessment of the meniscal injuries is presented in Table 1 (7). In our study, grade 1 and grade 2 meniscal injuries were considered degeneration; grade 3 was considered a meniscal tear (Figure 2a-c).

The imaging findings of OA are given in Table 2 (8). The findings of $O A$ were evaluated using the knee radiographs and the MRIs.

We used 2D fast spin echo (FSE) sequences with fat suppression to evaluate the ACL. Axial and coronal images were used for evaluating $A C L$ injuries.

\section{Statistical Analysis}

An IBM statistical software package (IBM SPSS Statistics version 20 for Windows; IBM SPSS Inc., Armonk, NY, USA) was used to perform all statistical calculations. The MannWhitney $U$ test was used in the two-group comparisons, and the Kruskal-Wallis $\mathrm{H}$ test was used in the comparisons of more than two groups because the variables were not normally distributed.

The mean, standard deviation (SD), and proportion were used as descriptive statistics. A p value of less than 


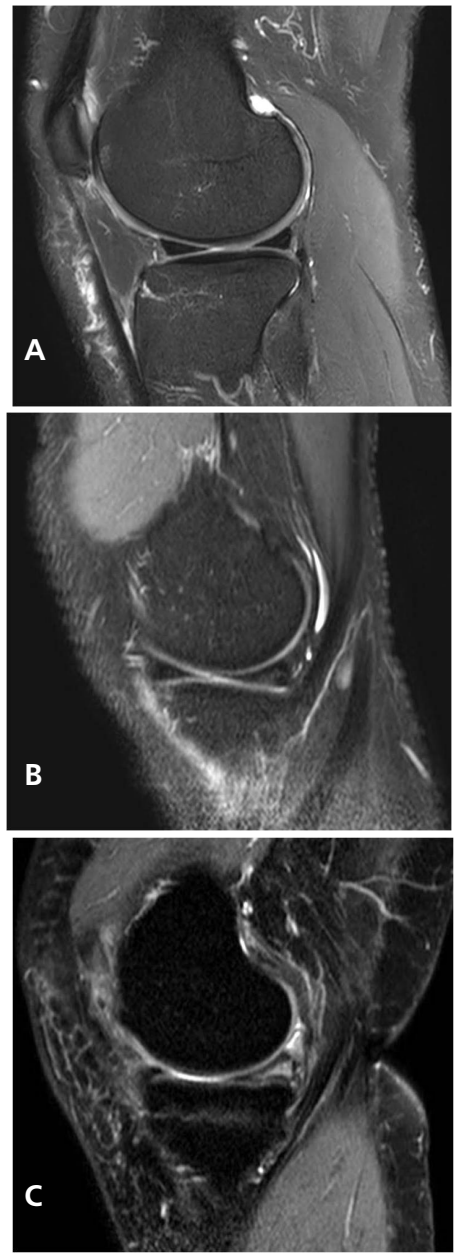

Figure 2. (a) Sagittal

T2-weighted spectral attenuated inversion recovery (SPAIR) MR image (TR/TE: 2619/62) shows a hyperintense focal area at the posterior horn. There is no extension to the articular surface (grade 1 degeneration). (b) Sagittal proton density (PD) SPAIR MR image (TR/TE: 3000/30) demonstrates linear areas of hyperintensity at the posterior horn. There is no extension to the articular surface (grade 2 degeneration). (c) Sagittal PD SPAIR MR image (TR/ TE: 3000/30) shows abnormal hyperintensity extends to the articular surface at the posterior horn [grade 3 (tear)] MR: Magnetic Resonance

\begin{tabular}{|l|l|}
\hline $\begin{array}{l}\text { Table 1. Magnetic resonance imaging grading system for } \\
\text { abnormal high meniscal signal intensity }\end{array}$ \\
\hline Grade 1 & $\begin{array}{l}\text { Small focal area of hyperintensity, no } \\
\text { extension to the articular surface }\end{array}$ \\
\hline Grade 2 & $\begin{array}{l}\text { Linear areas of hyperintensity, no } \\
\text { extension to the articular surface }\end{array}$ \\
\hline Grade 3 (tear) & $\begin{array}{l}\text { Abnormal hyperintensity extends to at } \\
\text { least one articular surface (superior or } \\
\text { inferior), and is referred as a definite } \\
\text { meniscal tear }\end{array}$ \\
\hline
\end{tabular}

\begin{tabular}{|l|l|}
\hline \multicolumn{2}{|l|}{ Table 2. The imaging findings of osteoarthritis } \\
\hline Radiography & Joint space narrowing \\
\cline { 2 - 2 } & Subchondral sclerosis \\
\cline { 2 - 2 } & Marginal osteophytes \\
\cline { 2 - 2 } & Subchondral cysts (geodes) \\
\cline { 2 - 2 } & $\begin{array}{l}\text { Altered shape of the femoral condyles and } \\
\text { tibial plateau }\end{array}$ \\
\hline MRI & Synovial thickening \\
\cline { 2 - 2 } & Bone marrow oedema \\
\cline { 2 - 2 } & Cartilaginous defects (partial or complete) \\
\hline MRI: Magnetic resonance imaging \\
\hline
\end{tabular}

0.05 was considered significant in all statistical analyses. All data are expressed as mean \pm SD and median (maximumminimum).

\section{Results}

\section{Patients}

In total, 101 knee joints (52 right, 49 left) belonging to 101 patients with the mean age 46.67 \pm 13.4 were included in the study. A total of 55 of the 101 patients were female (mean age: $49 \pm 10.8$ years), and 46 were male (mean age: 43.89 \pm 15.5 years) (Table 3 ).

\section{Radiologic Protocol and Imaging}

There were medial meniscal injuries in 64 knees. Of these, 31 were meniscal tears, 33 were grade 1 and 2 degeneration. The medial meniscus (MM) was normal in 37 knees (Table 4). There were lateral meniscal injuries in 26 knees. Of these, 9 were meniscal tears, 17 were grade 1 and 2 degeneration. The lateral meniscus (LM) was normal in 75 knees (Table 4).

The mean FTA value in the knees was $4.93 \pm 3^{\circ} \mathrm{C}$ for all patients. The mean FTA value in females and males was $4.91 \pm 3.1^{\circ} \mathrm{C}$ and $4.96 \pm 2.9^{\circ} \mathrm{C}$, respectively. The median FTA values of the MM and LM are shown in Table 5 . There was no statistically significant relationship between the FTA values and the presence of injury (degeneration or tear) in the medial and lateral menisci (Table 5).

Table 3. Distribution of patients by gender

\begin{tabular}{|l|l|l|l|l|}
\hline \multicolumn{2}{|c|}{} & Female & Male & Total \\
\hline \multirow{4}{*}{ Medial meniscus } & Degeneration & 21 & 12 & 33 \\
\cline { 2 - 5 } & Tear & 16 & 15 & 31 \\
\cline { 2 - 5 } & Normal & 18 & 19 & 37 \\
\hline \multirow{4}{*}{ Lateral meniscus } & Degeneration & 13 & 4 & 17 \\
\cline { 2 - 5 } & Tear & 5 & 4 & 9 \\
\cline { 2 - 5 } & Normal & 37 & 38 & 75 \\
\hline \multirow{3}{*}{$\begin{array}{l}\text { Anterior cruciate } \\
\text { ligament }\end{array}$} & Sprain & 7 & 7 & 17 \\
\cline { 2 - 5 } & Rupture & 5 & 10 & 15 \\
\cline { 2 - 5 } & Normal & 43 & 29 & 72 \\
\hline
\end{tabular}

Table 4. Distribution of the meniscus injuries according to right and left knee

\begin{tabular}{|l|l|l|l|l|}
\hline \multicolumn{2}{|c|}{} & Right & Left & Total \\
\hline \multirow{4}{*}{ Medial meniscus } & Degeneration & 18 & 15 & 33 \\
\cline { 2 - 5 } & Tear & 11 & 20 & 31 \\
\cline { 2 - 5 } & Normal & 23 & 14 & 37 \\
\hline \multirow{3}{*}{ Lateral meniscus } & Degeneration & 6 & 11 & 17 \\
\cline { 2 - 5 } & Tear & 4 & 5 & 9 \\
\cline { 2 - 5 } & Normal & 42 & 33 & 75 \\
\hline
\end{tabular}




\begin{tabular}{|c|c|c|c|c|c|c|}
\hline \multicolumn{2}{|l|}{ Minimum } & \multicolumn{5}{|l|}{ FTA } \\
\hline & & Maximum & Median & Range & p & \\
\hline \multirow[t]{3}{*}{ Medial meniscus } & Degeneration & 1 & 11 & 5 & 10 & \\
\hline & Normal & 0 & 12 & 4 & 12 & $>0.01$ \\
\hline & Tear & 1 & 12 & 4 & 11 & \\
\hline \multirow[t]{3}{*}{ Lateral meniscus } & Degeneration & 1 & 12 & 4 & 11 & \\
\hline & Normal & 0 & 12 & 4 & 12 & $>0.01$ \\
\hline & Tear & 1 & 12 & 5 & 11 & \\
\hline \multirow[t]{3}{*}{ Anterior cruciate ligament } & Sprain & 0 & 7 & 4 & 7 & \\
\hline & Normal & 1 & 12 & 4 & 11 & $>0.01$ \\
\hline & Rupture & 1 & 12 & 3 & 11 & \\
\hline
\end{tabular}

Forty-one of 101 patients (15 male, 26 female) had imaging findings of $O A$ in the knee joint $(20 \mathrm{R}, 21 \mathrm{~L})$. The knee joints (32 R, $28 \mathrm{~L}$ ) were normal in 60 patients (31 male, 29 female). The median FTA value in patients with the imaging findings of $\mathrm{OA}$ in the knee joint was $4^{\circ} \mathrm{C}(1-12)$. The median FTA value in patients with normal knee joints was $4^{\circ} \mathrm{C}(1-12)$. There was no statistically significant difference in FTA value between these two groups $(p>0.01)$.

Fourteen of the 101 patients had sprains in the $A C L$, and 15 had complete tears. This was detected by MRI. The ACL was normal in 72 patients. The median FTA value in patients with an $A C L$ sprain was $4^{\circ} \mathrm{C}(0-7)$; it was $3^{\circ} \mathrm{C}$ (1-12) in those with $\mathrm{ACL}$ rupture. The median FTA was $4^{\circ} \mathrm{C}$ (1-12) in patients with normal ACL (Table 3). There was no statistically significant relationship between the FTA values and the presence of injury (sprain or rupture) in the $\mathrm{ACL}$ (Table 5).

\section{Discussion}

Menisci are important structures of the knee joint. They increase stability for femorotibial articulation, distribute the axial load, absorb shock, and provide lubrication and nutrition to the knee joint. The meniscus is responsible for supporting $40-70 \%$ of the load in the knee. The remaining load is distributed by direct contact with the articular cartilage (2). Menisci are wedge-shaped, semilunar, fibrocartilaginous structures. There are two menisci in the knee: the MM and the LM (1). MRI is the most accurate and least invasive method for diagnosing meniscal lesions. In addition, soft tissues, articular cartilage, tendon injuries, and ligaments can be evaluated better with an MRI than with other imaging methods $(1,3)$. A normal meniscus is seen as a triangular-shaped low intensity signal on T1- and T2-weighted sequences or on FSE sequences (1).

Meniscal injuries increase with age and are often associated with and contribute to degenerative joint disease (1). The MM is less mobile than the $L M$ and is more susceptible to injury. Because the posterior horn of the MM absorbs most of the weight of the medial compartment, a posterior horn MM tear is common. Lateral meniscal tears are more common in the younger population and frequently occur secondary to acute trauma $(1,3)$. The criteria of the meniscal tears diagnosing with MRI include either an increased intrasubstance signal unequivocally contacting the articular surface or meniscal distortion in the absence of prior surgery. The positive predictive value for a tear is $94 \%$ in the MM and $96 \%$ in the LM, if these findings are seen on two or more images. Also, imaging findings should be accepted as a meniscal tear (1). These imaging findings must be detected in the same area on any two consecutive MR images. These consecutive images can be two coronal images, two sagittal images, or one coronal and one sagittal image

In their study evaluating 114 knee joints of 101 patients, Sirik (3) reported that the mean FTA value was $5.6 \pm 1.88$ in the knee joints with a MM injury and $5.8 \pm 1.92^{\circ} \mathrm{C}$ in the normal knee joints. This was not statistically significant $(p=0.82)$. In our study, the median FTA value was $4^{\circ} \mathrm{C}(1$ 12 ) in the knee joints with a medial meniscal injury and $4^{\circ} \mathrm{C}$ $(0-12)$ in the normal knee joints. This was not statistically significant $(p>0.01)$. Sirik (3) reported that the mean FTA value was $6.1 \pm 1.50^{\circ} \mathrm{C}$ in the knee joints with a $L M$ injury and $5.6 \pm 1.96^{\circ} \mathrm{C}$ in the normal knee joints. This was not statistically significant $(p=0.20)$. In our study, the median FTA value was $5^{\circ} \mathrm{C}(1-12)$ in the knee joints with a lateral meniscal injury and $4^{\circ} \mathrm{C}(0-12)$ in the normal knee joints. This was not statistically significant $(p>0.01)$.

$O A$ is referred to as degenerative arthritis or degenerative joint disease. $\mathrm{OA}$ is characterized by the progressive deterioration of the articular cartilage or of the entire joint, including the articular cartilage, the synovium (joint lining), the ligaments, and the subchondral bone (bone beneath the cartilage) (4). Radiological imaging 
methods for the evaluation of OA include AP and lateral radiographs, CT and MRI. Knee radiography is still the most commonly used imaging technique for evaluating a patient with a known or suspected diagnosis of OA. In addition, the radiograph is cheaper than the other imaging methods, and it is very accessible $(5,6)$. Changes in the FTA value disrupt knee alignment. Malalignment of the knee is an important risk factor for the development of knee OA $(5,6)$. In our study, the median FTA value was $4^{\circ} \mathrm{C}(1-12)$ in the knee with $\mathrm{OA}$ and $4^{\circ} \mathrm{C}(0-12)$ in the normal knee joint. This was not statistically significant ( $p>0.01)$.

The ACL is the most important structure that provides the normal biomechanics of the knee. One of the most common knee injuries is a sprain or tear (9). The normal $\mathrm{ACL}$ should have a taut, low-to intermediate-signal intensity with continuous fibers in all planes and sequences. It courses parallel to or steeper than the intercondylar line. The primary sign of an $A C L$ tear is discontinuity in the fibers. The accuracy, sensitivity, and specificity of MRI in $\mathrm{ACL}$ ruptures are more than $90 \%$. Oblique sagittal plane with coronal and axial images is very useful in diagnosis. The empty notch sign on coronal imaging is a frequent finding in a complete ACL tear (9). A sprain involves the overstretching of the ligaments, which are the fibrous connective tissues that connect the bones to one another and stabilize them. In our study, the median FTA value was $3^{\circ} \mathrm{C}(1-12)$ in knees with $\mathrm{ACL}$ tear and $4^{\circ} \mathrm{C}(1-12)$ in normal $A C L$. This was not statistically significant $(p>0.01)$.

\section{Conclusion}

In our study, there was no statistically significant relationship between the FTA values and the presence of injury (degeneration or tear) in medial and lateral menisci. In addition, there was no statistically significant relationship between the FTA values and the development of OA. We considered that there was no relationship between malalignment of the knee and changes in FTA value.

\section{Authorship Contributions}

Concept: E.S., A.T.S. Design: E.S., A.T.S. Data Collection or Processing: E.S., A.T.S. Analysis or Interpretation: E.S. Literature Search: A.T.S. Writing: E.S.

Conflict of Interest: No conflict of interest was declared by the authors.

Financial Disclosure: The authors declared that this study received no financial support.

\section{References}

1. Nguyen JC, De Smet AA, Graf BK, Rosas HG. MR imagingbased diagnosis and classification of meniscal tears. Radiographics 2014;34:981-99.

2. Costa CR, Morrison WB, Carrino JA. Medial meniscus extrusion on knee MRI: is extent associated with severity of degeneration or type of tear? AJR 2004;183:17-23.

3. Sirik M. Evaluation of the relationship between the femorotibial angle and meniscal injury. North Clin Istanb 2017;4:2426.

4. Sharma L, Song J, Felson DT, Shamiyeh E, Dunlop DD. The role of knee alignment in disease progression and functional decline in knee osteoarthritis. JAMA 2001;286:188-95.

5. Brouwer GM, Van Tol AW, Bergink AP, et al. Association between valgus and varus alignment and the development and progression of radiographic osteoarthritis of the knee. Arthritis Rheum 2007;56:1204-11.

6. Yang NH, Nayeb Hashemi H, Canavan PK, Vaziri A. Effect of frontal plane tibiofemoral angle on the stress and strain at the knee cartilage during the stance phase of gait. J Orthop Res 2010;28:1539-47.

7. Li CA, Kim MK, Kim IH, Lee JH, Jang KY, Lee SY. Correlation of histological examination of meniscus with MR images: Focused on high signal intensity of the meniscus not caused by definite meniscal tear and impact on MR diagnosis of tears. Korean J Radiol 2013;14:935-45.

8. Braun HJ, Gold GE. Diagnosis of Osteoarthritis: Imaging. Bone 2012;51:278-8.

9. Ng WH, Griffith JF, Hung EH, Paunipagar B, Law BK, Yung PS. Imaging of the anterior cruciate ligament. World J Orthop 2011;2:75-84. 